\author{
Samofatova V. \\ Ph.D. in Economics, Doctoral candidate \\ Department of Industrial Economics \\ Odessa National Academy of Food Technologies \\ Kanatna str., 112, Odesa, Ukraine, 65039 \\ E-mail: vica_samofatova@meta.ua
}

\title{
THEORETICAL FOUNDATIONS OF SUSTAINABLE DEVELOPMENT OF THE AGRI-FOOD SPHERE
}

The article highlights the historical preconditions and principles of sustainable development of the agri-food sphere. The analysis of the evolution of the categorical content of sustainable development is carried out. It has been noted that the main ideology of sustainable development is the integration and harmonization of the ecological, economic and social spheres of society. It is shown that the concept of sustainable development has an interdisciplinary character, so it should be considered in many aspects and studied from different angles. The basic advantages of sustainable development for the agri-food sphere are outlined.

Key words: sustainable development, the concept of sustainable development, agri-food sphere (AFS), the principles of sustainable development, strategy.

This work is licensed under a Creative Commons Attribution 4.0 International License http://creativecommons.org/licenses/by/4.0/

Statement of the problem and its connection with important scientific and practical tasks. The modern stage of social development has led to an intensification of the contradictions of the interaction between man and nature. A complicated and comprehensive phenomenon as "sustainable development of society" is the subject of research by a wide range of specialists in economics, sociology, ecology and the field of interest of a number of organizations and research institutions. This points out the interdisciplinary concept of sustainable development, so it should be considered in many aspects and studied from different angles. In particular, in the late 1980s, the Swedish Royal Academy of Sciences established the International Institute of Ecological Economics, for combining economic disciplines and ecology and, more generally, the natural and social sciences [1].

The concept of sustainable development is generated by the needs of modern human development and has an important, growing importance every decade for the management of natural and social processes in the global as well as regional and local scales. The basis of the ideology of sustainable development is the integration and harmonization of the ecological, economic and social spheres of society. In the center of the concept of sustainable development is a person, since she is the goal of social activity with her needs, and it is also the main factor in achieving the goal. Among the main factors contributing to sustainable development, we can distinguish the following:

- ecological - defines the conditions and limits of the restoration of ecological systems as a result of their exploitation;
- economic - involves the formation of the economic system, harmonized with the ecological factor of development;

- social - establishes the right of a person to a high standard of living in conditions of ecological safety and well-being [2, p.3].

At present, the concept of "sustainability" is substantially expanded and is considered, as a rule, within the framework of co-evolutionary development of nature and society. The most important principles of such development are the preservation of high quality of the environment, economic development within the limits of limited resources, and solving of social problems.

The analysis of the latest publications on the problem. The theoretical foundations of sustainable development of the society were studied by many domestic and foreign scientists in their papers: V. Bautin [7], G. Daly [6], Dennis Meadows [5], Donella Meadows [5], O. Popova [10], S. Sonko [8], M. Khvesik [4], O. Shubalyi [4], K. Holling [2], and other researchers. Careful elaboration of their works gives an impetus for further development of grounds of the theoretical basis for the characterization of sustainable development in the agri-food sphere (AFS). At the same time, the theory of sustainable development is at the stage of making, as there are many controversial and unresolved issues that actualizes the task of systematic analysis of scientific views and their further development, acceptable to the AFS.

Forming of the aims of the research. The purpose of the article is to conduct the analysis of theoretical and methodological principles for the interpretation of the concept of "sustainable development" and the substantiation of its essence in the agri-food sphere, with the 
presentation of the author's vision of its contemporary content.

Giving an account of the main results and their substantiation. Development is a complicated process and change of unstable development into a sustainable one should be accompanied by the elimination of all negative factors in the functioning of a complex socioeconomic system. As you know, the term "sustainable development" means supported, balanced, selfreproductive development, in other words, one that would be consistent with the resource and environmental capabilities of the biosphere. The concept of "sustainable development" itself was introduced at the 42nd session of the United Nations (1987) in the report of the commission "Our Common Future" [3]. The report also noted that "the strategy of sustainable development is aimed at achieving harmony between people and between society and nature" [3, p. 68]. In other words, sustainable development of society is possible only in the case of a harmonized relationship both within society and with the environment.

There is no doubt that, sustainable development is a systemic problem and like any system consists of many elements. According to M. Khvesik and O. Shubalyi, "the development process takes place in, at least, two opposite ways: variability and stability, chaos and order, involution and evolution. In this unity of interconversions and opposite moments of development, the notion of sustainable development focuses on the evolution, coherence and direction of changes. Order and safety are inherent in the process of such development as well as survival and preservation of structures, contrary to chaos and catastrophe. Thus, sustainable development is such a creative evolution of the system, in which no transformation within the system, no external negative factors can bring it out of the state of dynamic equilibrium "[4, p. 67].

In 2004, Donella Meadows, Jorgen Randers, Dennis Meadows published the book "Beyond the Growth", which corrects the scenarios of the original model based on 30-year data since the publication of the first report of the Club of Rome [5]. The author of the Innovation Economic Theory of Sustainable Development, highlighted in the monograph: "Beyond Growth: The Economic Theory of Sustainable Development" (1996), is the American economist G. Daly. According to G. Daly, "sustainable development is the definition of harmonious, balanced, non-conflict progress of all earthly civilization, groups of countries, individual countries of our planet based on scientifically grounded plans, when simultaneously a complex of issues on environmental protection, liquidation of exploitation, poverty and discrimination both of each separate person, and entire peoples or groups of people is solved [6, p. 28].

Sustainable development as a balanced interaction between man, society and nature must be socially oriented, aimed at the formation of intelligent human needs, in connection with which the implementation of its principles involves adjusting the scale of vital values in the direction of growth of moral and spiritual components.
According to V. Boutin and other co-authors of the monograph, "the fundamental difference between the concept of sustainable development and traditional views and practices of management lies in the integral approach to development as an integral process of nature, population, economy" [7, p. 56]. Although the world continues to move through unsustainable development, due to the increasing number of global problems and manifestations of the negative effects of these problems, sustainable development is becoming increasingly relevant, so the transition to such development is inevitable. It should be noted that humanity has two ways - a global catastrophe or the creation of a sustainable society, based on the noosphere concept, where technologies are used for the benefit of man and nature. According to S. Sonko, humanity should maximally approximate all technologies and other forms of nature use to the mechanism of formation of substance-energy metabolism in natural ecosystems, adhering to the principle of limit sufficiency. A limit is considered sufficient, when passing through it, mankind is at risk of self-destruction [8, p. 4]. The approach of geographical space to the level of constancy means gradual return to mechanisms of substance-energy exchange, having a spatial manifestation in natural ecosystems and agroecosystems. Agroecosystems are agricultural enterprises, typical socio-natural ecosystems, which people form on the basis of their interests, but at the expense of the use of organisms created by nature itself (although altered by them in the process of artificial selection).

Sustainable development meets the interests of any state. A clear, grounded national strategy for sustainable development is a key to bringing Ukraine closer to world standards of socio-economic and environmental progress. In the national paradigm of sustainable development of Ukraine, it means "the process of harmonizing productive forces, ensuring satisfaction of the indispensable needs of all members of society in the conditions of preservation and phased reproduction of the integrity of the natural environment, creating opportunities for balancing between its potential and the requirements of people of all generations" [9, p. 4].

The main characteristics, on which the study of sustainable development of the society are based, and which are the core of national and regional development models, include:

- Balance as a reconciliation of social, economic and environmental interests;

- harmony of coexistence of nature and society;

- stability of satisfying needs;

- the balance between economic benefits, social needs and natural benefits;

- resistance to the influence of negative factors.

In the philosophical sense, sustainable development is a spiral development. Elements of cyclic recurrency, regular repetition of events, phenomena and processes are combined with a unidirectional sequential trajectory. According to the classical definition, sustainable development is interpreted as a coherent development of economic, social processes and the natural environment. Summarizing various theories and perspectives on 
the sustainability of development, one can come to the conclusion that it characterizes the ability of the socioeconomic system to withstand the internal and external factors of influence and the ability to adapt to them.

And although, as the historical reality shows, linear, stable development in the society does not exist, everything happens cyclically, periodically and wavelike, the phases of growth change to recessions, crises, depressions, regression, but the intensity of the change of one stage of development to another can occur with different strength, amplitude and frequency, on which the concept of sustainability and the balance of development are based. Consequently, sustainable development should be seen as the harmonious coexistence of human civilization with the natural environment on a sustainable, long-term basis by ensuring a balance between economic benefits, social interests and natural benefits. Now the system of phenomena of the real world is no longer doubtful. Therefore, objects and processes should be considered as a system, that is, as a set of components, relationships and connections, including interactions with the environment. In the process of development, consisting of cyclically repeating stages of evolution, the system constantly moves from a steady state to an unstable one and vice versa. Structural and functional constancy, under which we understand the ability of the system to maintain its parameters in a certain area of values, that allow them to maintain a high-level certainty, including composition, relationships and behaviour (but not equilibrium), is formed in the process of adaptation to the changing internal and external conditions of management.

The study of the methodology of sustainable development is of great practical importance, especially for the implementation of this concept in the activities of the agri-food sphere (AFS). AFS is based on agrarian production, food industry and food market and at the same time, is the most important component of national and regional economic systems. The concept of AFS is much broader than the concept of "agri-food complex" (AFC), because in addition to the traditional components of the agri-industrial complex, it takes into account the complex territorial subsystem. AFS is the subject of the concept of sustainable development, due to its essence direct involvement in the environment, consumption of natural resources and significant anthropogenic impact on the environment - degradation and pollution of land, water and other resources. The key problems of the development of AFS are the low commodity production, the weakening of the economic basis for the development of the countryside, the significant losses of production due to the imperfection of the infrastructure of the agrarian market, in particular the lack of agricultural cooperation and storage logistics, lack of incentives for producers to comply with agri-environmental requirements of production, limited solvent demand of the population and many others.

Recognition of the relationship between environmental, economic and social systems is a fundamental methodological position that determines the origins of AFS's sustainable development policy. It is AFS that is one of the most important bases for the development of our state. The main objective of the concept of sustainable development in the AFS should be achievement of an optimal balance between economic growth, the normalization of the quality of natural resources and satisfaction of the needs of the population in high-quality food products. Sustainable development of AFS requires a certain strategy, that is, the definition of long-term goals of rational use and reproduction of natural and resource, human and productive potentials.

According to O. Popova's interpretation, sustainable development of the agri-food sphere is a systematic, oriented towards the interests and potential of man and society, in general adaptive in nature and qualitative, in point of fact intrinsically targeted changes, accompanied by increased ecological and economic efficiency, socioeconomic progressiveness and environmental sustainability, both the case of previous invariant states, and as for achievement of rational models of constancy at various stages of evolutionary development [10, p. 75]. It should also be noted that the sustainable development of AFS is the ability of all its sectors to dynamically maintain proportions of the effective development, to carry out expanded reproduction, and to form food security of the country. Under the constant development of AFS, we understand the coherent process of, the consistent implementation of systems of technological and managerial decisions, the use of which is focused on the conservation and effective use of natural and resource potential and solving of social, environmental and economic objectives. An important factor for sustainable development is the integration processes and the creation of clusters in the AFS. Sustainable development of AFS is also impossible without the profile, successfully functioning and competitive science and education.

The sustainability of AFS has its own distinct differences, to which we refer soil-climatic, biological, and environmental factors; technologies of cultivation and processing of agricultural products, organization of rural territories and rural-urban continuum. Constancy of production is the most important condition for the effective development of AFS. The main deterrent factors of sustainable development are deterioration of fertility and soil condition, price imbalances in the APS, financial inaccessibility of credit resources, insufficient development of innovative processes, reduction of labor potential in rural areas and in small agricultural cities.

Conclusions and prospects of the further investigations. The considered approach to expanding the content of the concept of "sustainable development" and levels of its integration creates the initial preconditions for the further development of the theory of management of the sustainable development of the agricultural sphere of the region and the development of basic provisions. Obviously, sustainable development is based on both global factors and taking into account the specifics character of individual regions, its human, natural and resource, innovation, geographic and transport potentials. That is all, that provides the reproduction process - the basis of the system of sustainable development. Achieving the sustainable development of the agri-food sphere should be based on the relevant principles of 
management. Among the basic principles of management should be include: the principle of the combination of state regulation and market self-regulation; the principle of prevalence of multi-sectoral economic structures; the principle of sustainable and priority development of the social and labour sphere in the countryside; the principle of priority of environmental and economic substantiation of economic decisions.

\title{
References
}

1. The Beijer Institute of Ecological Economics. Retrieved from http://www.beijer.kva.se

2. Holling, C. S. 2000. Theories for sustainable futures. Conservation Ecology 4(2): 7. [online] URL. Retrieved from http://www.consecol.org/vol4/iss2/art7/

3. Our Common Future. The Brundtland Report of the World Commission on Environment and Development. V. Hauff - 1987 - Oxford Univ. Press, Oxford. [Elektronnyi resurs]. Retrieved from http://www.un.org/ru/ga/pdf/brundtland.pdf

4. Khvesyk, M. A., \& Shubalyi, O. M. (2011). Suchasna paradyhma staloho rozvytku v umovakh hlobalizatsii. Konomika pryrodokorystuvannia i okhorony dovkillia: zb. nauk. prats, 3, 61-69.

5. Deili , H. (2002). Poza zrostanniam. Ekonomichna teoriia staloho rozvytku. K.: Intelsfera.

6. Meadows, D. H., Randers, J., \& Meadows, D. L. (2004). Limits to Growth: The 30-year Update. White River Jct. (VT). M.: Akademknyha, Chelsea Green Publ. Co.

7. Bautyn, V. M., Kozlov, V. V., \& Andreeva, N. P. (2004). Ustoichyvoe razvytye selskykh terrytoryi. M.: FHNU «Rosynformahrotekh».

8. Sonko, S. P. (2003). Heohrafichna interpretatsiia dopovidei Rymskomu klubu. Ukrainskyi heohrafichnyi zhurnal, 1, 55-62.

9. Natsionalna paradyhma staloho rozvytku Ukrainy. (2012). K.: Derzhavna ustanova «Instytut ekonomiky pryrodokorystuvannia ta staloho rozvytku Natsionalnoi akademii nauk Ukrainy».

10. Popova , O. (2012). -sotsioekonomichnyi zmist i zasady staloho rozvytku. Ekonomika Ukrainy, 5, 73-84.

Received 27 June 2017

Approved 12 July 2017

Available in Internet 30.09.2017

\author{
Самофатова B.A. \\ кандидат экономических наук, докторант \\ кафедра экономики промышленности \\ Одесская национальная академия пищевых технологий \\ ул. Канатная, 112, г. Одесса, Украина, 65039 \\ E-mail:vica_samofatova@meta.ua
}

\section{ТЕОРЕТИЧЕСКИЕ ОСНОВЫ УСТОЙЧИВОГО РАЗВИТИЯ АГРОПРОДОВОЛЬСТВЕННОЙ СФЕРЫ}

В статье рассмотрены исторические предпосылки и принципы устойчивого развития агропродовольственной сфреры. Осуществлён анализ эволюции категориального содержания устойчивого развития. Отмечено, что основной идеологией устойчивого развития является интеграция и гармонизация экологической, экономической и социальных сфер общества. Наиболее важными принципами устойчивого развития является сохранение высокого качества окружающей среды, экономическое развитие в рамках ограниченных ресурсов, решение социальных проблем. Другими словами, устойчивое развитие общества возможно только в том случае, когда гармонизированы отношеня как внутри общества, так и с окружающей средой. Акцентировано внимание на том, что в центре концепции устойчивого развития находится человек, поскольку он с его потребностями является целью общественной деятельности, и он же есть основным фрактором достижения цели. Показано, что концепция устойчивого развития носит междисциплинарный характер, поэтому её следует рассматривать во многих аспектах и изучать из разных ракурсов. Сделан вывод, что человечество должно максимально приближать все технологии и другие фрормы природопользования к механизму фрормирования сырьевого и энергетического обмена в природных экосистемах. Обобщая различные теории и точки зрения на устойчивость развития, сделан вывод, что оно характеризует способность социальноэкономической системы сопротивляться внутренним и внешним факторам влияния и умение адаптироваться к ним.

Отмечено, что исследование методологии устойчивого развития имеет огромное практическое значение, особенно для агропродовольственной сферы (АПС). Очерчены базовые преимущества устойчивого развития для АПС. Эта сфера непосредственно связана с использованием природных ресурсов для обеспечения собственной производственной деятельности. Признание взаимосвязей между экологической, экономической и социальными системами является фундаментальной методологической позицией, которая определяет истоки устойчивого развития АПС. Важным фрактором устойчивого развития являются интеграционные процессы и создание кластеров в АПС. Устойчивое развитие АПС также невозможно представить без профильных, успешно функционирующих и конкурентоспособных науки и образования. 
Ключевые слова: устойчивое развитие, концепция устойчивого развития, агропродовольственная сфера (АПС), принципы устойчивого развития, стратегия.

Самофратова В.A.

кандидат економічних наук, докторант кафедра економіки промисловості

Одеська національна академія харчових технологій вул. Канатна, 112, м. Одеса, Україна, 65039

E-mail: vica_samofatova@ meta.ua

\section{ТЕОРЕТИЧНІ ЗАСАДИ СТАЛОГО РОЗВИТКУ АГРОПРОДОВОЛЬЧОї СФЕРИ}

У статті розглянуті історичні передумови та принципи сталого розвитку агропродовольчої сфери. Здійснено аналіз еволюції категоріального змісту сталого розвитку. Відзначено, що основною ідеологією сталого розвитку $є$ інтеграція і гармонізація екологічної, економічної та соціальних сфер суспільства. Найбільш важливими принципами сталого розвитку є збереження високої якості навколишнього середовища, економічний розвиток в рамках обмежених ресурсів, вирішення соціальних проблем. Іншими словами, сталий розвиток суспільства можливий тільки в тому випадку, коли гармонізовані відношення як всередині суспільства, так і з навколишнім середовищем. Акцентовано увагу на тому, що в центрі концепції сталого розвитку знаходиться людина, оскільки вона з його потребами $є$ метою суспільної діяльності, і вона також є основним фрактором досягнення мети. Показано, що концепція сталого розвитку носить міждисциплінарний характер, тому її слід розглядати в багатьох аспектах і вивчати з різних ракурсів. Зроблено висновок, що людство повинно максимально наближати всі технології та інші фрорми природокористування до механізму фрормування сировинного та енергетичного обміну в природних екосистемах. Узагальнюючи різні теорії і точки зору на сталість розвитку, зроблено висновок, що воно характеризує здатність соціально-економічної системи протистояти внутрішнім і зовнішнім факторам впливу і вміння адаптуватися до них.

Відзначено, що дослідження методології сталого розвитку має велике практичне значення, особливо для агропродовольчої сфери (АПС). Окреслено базові переваги сталого розвитку для АПС. Ця сфрера безпосередньо пов'язана з використанням природних ресурсів для забезпечення власної виробничої діяльності. Визнання взаємозв'язків між екологічною, економічною та соціальними системами є фундаментальною методологічною позицією, яка визначає витоки сталого розвитку АПС. Важливим фактором сталого розвитку є інтеграційні процеси і створення кластерів в АПС. Сталий розвиток АПС також неможливо уявити без профільних, успішно функціонуючих і конкурентоспроможних науки і освіти.

Ключові слова: сталий розвиток, концепція сталого розвитку, агропродовольча сфера (АПС), принципи сталого розвитку, стратегія.

\section{Література}

1. The Beijer Institute of Ecological Economics. http://www.beijer.kva.se

2. Holling, C. S. 2000. Theories for sustainable futures. Conservation Ecology 4(2): 7. [online] URL: http://www.consecol.org/vol4/iss2/art7/

3. Our Common Future. The Brundtland Report of the World Commission on Environment and Development. V. Hauff - 1987 - Oxford Univ. Press, Oxford. [Електронний ресурс] - Режим доступу: http://www.un.org/ru/ga/pdf/brundtland.pdf

4. Хвесик М. А. Сучасна парадигма сталого розвитку в умовах глобалізації / Хвесик М.А., Шубалий О.М. // Економіка природокористування і охорони довкілля: зб. наук. праць. - 2011 - № 3. - С.61 - 69.

5. Дейлі Г. Поза зростанням. Економічна теорія сталого розвитку / Г.Дейлі. - К.: Інтелсфера. - 2002. - 211

c.

6. Meadows D. H., Randers J., Meadows D. L. Limits to Growth: The 30-year Update. White River Jct. (VT): Chelsea Green Publ. Co., 2004. 338 р. (рус. перевод "Пределы роста. 30 лет спустя". М.: Академкнига, 2007.342 с.

7. Устойчивое развитие сельских территорий / [В.М. Баутин, В.В. Козлов, Н.П. Андреева и др.]. - М.: ФГНУ «Росинформагротех», 2004. - 312 с.

8. Сонько С. П. Географічна інтерпретація доповідей Римському клубу / С. П. Сонько // Український географічний журнал. - 2003. - № 1. - С. 55-62.

9. Національна парадигма сталого розвитку України / за заг. ред. академіка НАН України Б. С. Патона. - К.: Державна установа «Інститут економіки природокористування та сталого розвитку Національної академії наук України», 2012. - 72 с.

10. Попова О. Агросфера: соціоекономічний зміст і засади сталого розвитку / О. Попова // Економіка України. - 2012. - № 5. - С. 73-84.

Стаття надійшла 27.06.2017 Стаття прийнята до друку 12.07.2017 Доступно в мережі Internet 31.09.2017 